\title{
A CHARACTERIZATION OF THE SINE FUNCTION BY FUNCTIONAL INEQUALITIES
}

\author{
IWONA TYRALA
}

Abstract. In the present paper we deal with the first generalization of Wilson's difference

$$
f(x) g(y)-f\left(\frac{x+y}{2}\right)^{2}+f\left(\frac{x-y}{2}\right)^{2},
$$

assuming that its absolute value is majorized by some function in a single variable.

Mathematics subject classification (2010): 39B62, 39B82.

Keywords and phrases: stability, d'Alembert's equation, Wilson's equation, functional inequality.

\section{REFERENCES}

[1] J. AcZÉL, Functional equations and their applications, Academic Press, 1966.

[2] J. ACZÉL, J. Dhombres, Functional equations in several variables, Cambridge University Press, 1989.

[3] R. BADORA, On the stability of the cosine functional equation, Rocznik Naukowo-Dydaktyczny WSP w Krakowie, 196 (1998), 1-14.

[4] R. BADORA, On Hyers-Ulam stability of Wilson's functional equation, Aequationes Math., 60 (2000), 211-218.

[5] R. BAdora, R. Ger, On some trigonometric functional inequalities, Functional Equations-Results and Advances, Kluwer Academic Publishers (2002), 3-15.

[6] J.A. BAKeR, The stability of the cosine equation, Proc. Amer. Math. Soc., 80 (1980), 411-416.

[7] P. GǍVRUTǍ, A generalization of Hyers-Ulam-Rassias stability of approximately additive mappings, J. Math. Anal. Appl., 184 (1994), 431-436.

[8] P. W. Cholewa, The stability of the sine equation, Proc. Amer. Math. Soc., 88 (1983), 631-634.

[9] R. GER, Christensen measurability and functional equations, Berichte der Mathematisch-Statistischen Sektion in der Forschungsgessellschaft Joanneum-Graz, Bericht 289 (1988), 1-17.

[10] D.H. Hyers, G. IsAC, Th.M. Rassias, Stability of functional equations in several variables, Birkhauser-Boston-Basel-Berlin, 1998.

[11] Pl. Kannappan, The functional equations $f(x y)+f(x y)^{-1}=2 f(x) f(y)$ for groups, Proc. Amer. Math. Soc., 19 (1968), 69-74.

[12] Z. Moszner, On the stability of functional equations, Aequationes Math., 77 (2009), 33-88.

[13] W.H. WiLson, On certain related functional equations, Bull. Amer. Math. Soc., 26 (1919), 300-312. 